\title{
DES SOIES
}

je me rappellerai une dame, âgée et penchée, aguerrie de sa chambre, avec un genêt,

balayant et nettoyant les soies, pour astiquer ses planches;

j'apercevrai les oiseaux qui viennent, plongeant et becquetant; ça, c'est infini;

la dame les regarde parfois, prend son souffle, soulève son genêt, balaie, puis les balaie à nouveau.

\section{David Radd}

The University of Kansas 


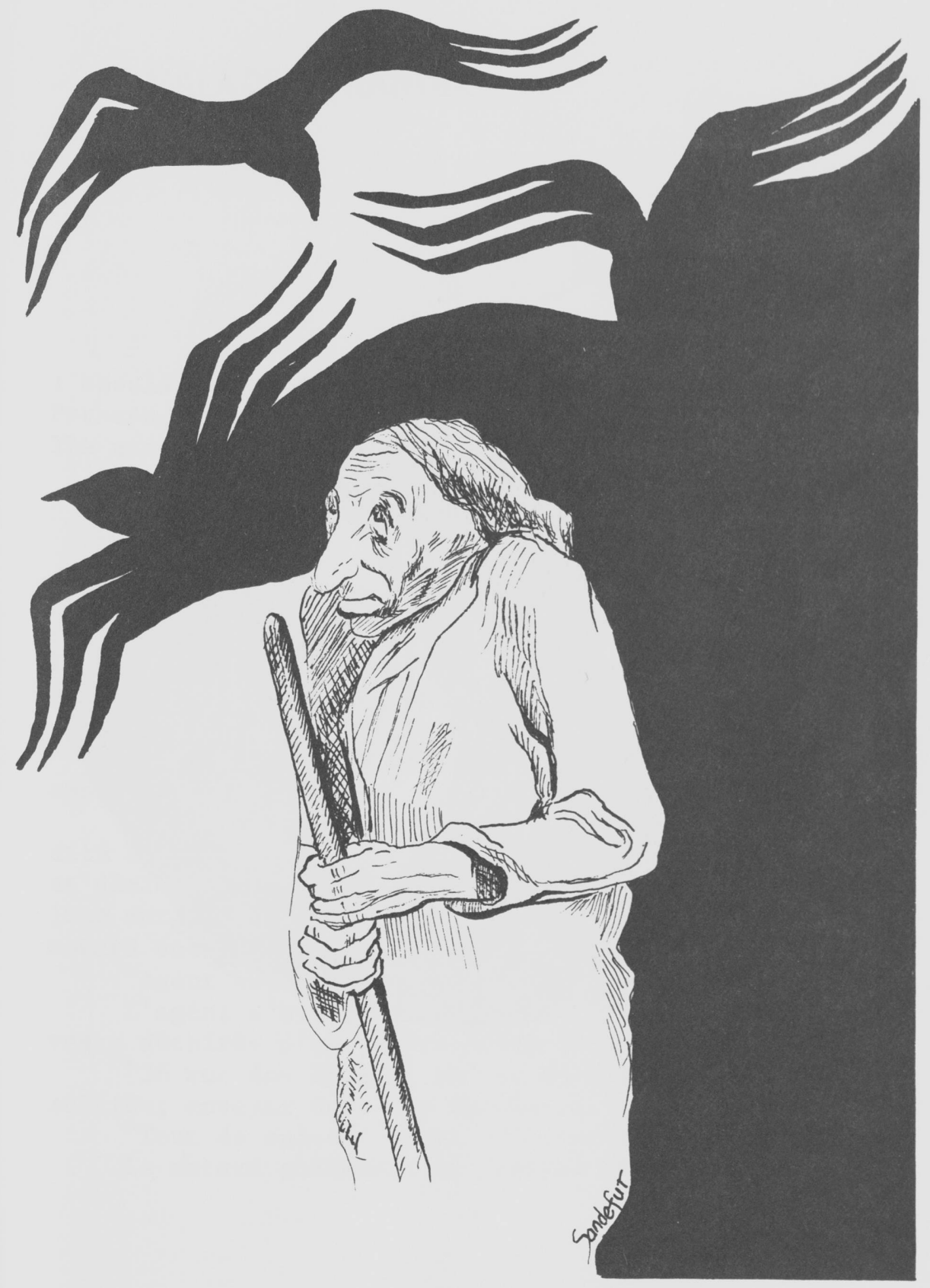




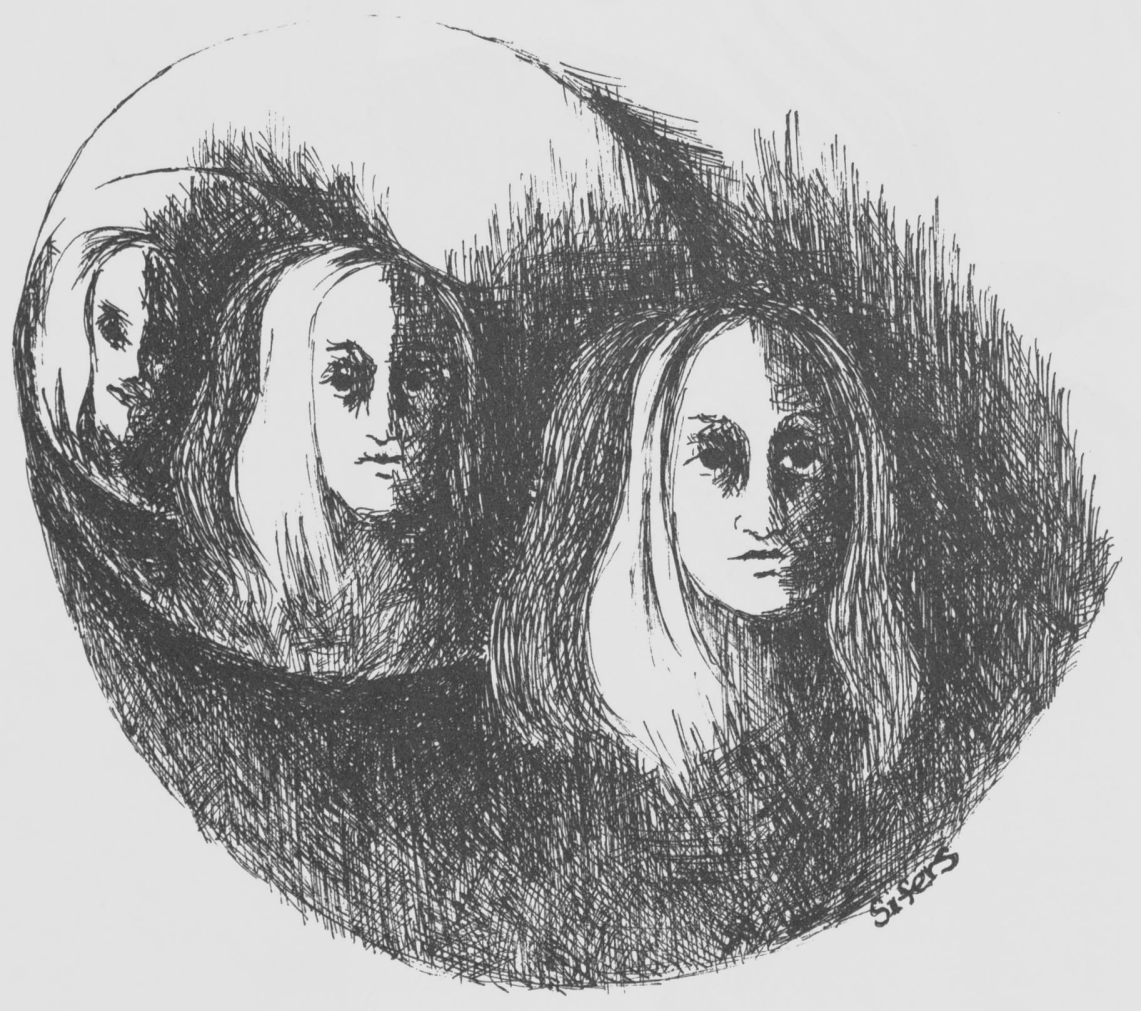

